\title{
Investigation on a CI Engine Fuelled with blends of Waste Tyre oil
}

\author{
[K. Vijaya Kumar, Dr. Ravi Kumar Puli, D. Ravichandra, K. Abhishek]
}

\begin{abstract}
Current ages of science and technology running towards the control of environmental degradation and improvement of energy to meet the rush of rising demand. On the other hand bearing in mind the breeding consumptions of crude reservoirs are across the world. Developing countries like India depend heavily on crude oil import of about thousand barrels per day. Transportation sector consumes the major portion of imports, finding a suitable fuel alternative to diesel is an urgent need. In this regards focus has been gradually shifting towards energy recovery from waste materials which can solve both the problems. One of the major wastes in the automobile sector is automobile tyres. These have an adverse impact on the environment if they are not disposed off properly. Further, tyres are a source of high grade energy hence its improper disposal means wastage of energy. Several methods have been developed to extract energy from waste tyres. One of them is pyrolysis of tyre which produces Tyre Pyrolysis Oil (TPO) by thermal decomposition of tyres. Among the alternatives, production of liquid fuel would be a better alternative as the calorific value of tyres is comparable to that of fuels, around $43.8 \mathrm{MJ} / \mathrm{kg}$. Other properties of the oil derived from waste tyres were also similar to the petroleum-based diesel. In the present work, blends of $20 \%$, $40 \%, 60 \%, 80 \%$ Waste Tyre Oil with diesel and $100 \%$ TPO are considered to investigate the performance, and emission characteristics in an existing diesel engine. For better understanding of the results, an injection time of 230 BTDC, 200 bar fuel injection pressure, and a 3 holes injector is used throughout the investigation. Some better performance and emission characteristics were observed from all the blend ratios. However, $20 \%$ TPO and $80 \%$ diesel blend gave better results as compared to other waste tyre oil blends.
\end{abstract}

Keywords-Diesel, Waste Tyre Oil, Biodiesel, Compression Ignition Engine, Exhaust Gas Analyser.

\section{Introduction}

Waste disposal is becoming a serious problem in each and every sector of technology. It assumes greater significance in a country like India with a population greater than a billion.

K. Vijaya Kumar

Reasearch Scholar,MED, NIT Warangal, Telangana, INDIA .

Dr. Ravi Kumar Puli

Professor, MED, NIT Warangal, Telangana, INDIA.

D. Ravichandra

Reasearch Scholar, MED, NIT Warangal, Telangana, INDIA.

K. Abhishek

B.Tech, MED, NIT Warangal, Telangana, INDIA.
The growing demand for automobiles has generated huge amount of waste tyres and disposing it economically and in an environment friendly manner has become a challenge for many local and central governments around the globe. Legislative provisions have already been formed in many countries that require treatment of waste tyres before final disposal to landfill. The continuous increase in the management cost of waste tyres has led to illegal dumping and stockpiling, which are inherent costs to local authorities. Further the waste management techniques used in India is far inferior than the techniques used in other developed countries. Mostly they are either disposed off in landfills or in some inappropriate way such as illegal dumping. Waste minimization includes recycling, reusing and developing new process of toxicity reduction.

\subsection{Waste tyre Oil}

The waste tyre oil is produced from scrap tyres through pyrolysis process. Billion tons of wastages are obtained in the world which causes potential environmental hazards. We cannot burn or landfills those tyres due to pollution problems. There is no any other use of these waste tyres. So, we separate all substances from wastage tyres and make it complete renewable process.

The most attractive technique of chemical feedstock recycling is pyrolysis. Adrian M. Cunliffe et al., studied the composition of oils derived from the batch pyrolysis of tyres in a nitrogen purged static-bed batch reactor, used to pyrolyse $3 \mathrm{~kg}$ of shredded scrap tyres at temperatures between $450^{\circ} \mathrm{C}$ and $600^{\circ} \mathrm{C}$ [1]. Thermal cracking or thermal pyrolysis involves the degradation of the tyres by heating in the absence of oxygen. Isabel de Marco Rodriguez et al., In his work it is reported that Tyre Oils are a complex mixture of organic compounds of 5-20 carbons and with a higher proportion of aromatics. In this work, the percentage of aromatics, aliphatic, nitrogenated, benzothiazol was also determined in the Tyre pyrolysis oil at various operating temperatures of the pyrolysis process [3]. Murugan et al., 2006 further investigated the use of distilled tyre derived fuel blended with diesel fuel in CI engines. Higher exhaust emissions were observed when more than $80 \%$ by volume of tyre derived fuel in the blend was used. However no engine failure or reduced performance was observed. The waste tyre oil has compared with the petroleum products and found to be suitable as a fuel in CI engines [5].

\subsection{Fuel Injector}

The fuel injection system is the most vital component in the working of $\mathrm{CI}$ engine. The engine performance, power output, economy, etc. is greatly dependent on the effectiveness 
of the fuel injection system. The injection system has to perform the important duty of initiating and controlling the combustion process. Fuel is atomized into very fine droplets when it is being injected into the combustion chamber towards the end of the compression stroke by injector nozzle.

Here by increase in the number of holes and the size of the nozzle, the thermal efficiency was decreased, but the performance increases [15]. The injector nozzle hole size and number included $340 * 2(340 \mu \mathrm{m}$ diameter holes with 2 holes in the nozzle), $240 * 4,200 * 6$, and $170 * 8$ among all of these injector nozzle holes, with biodiesel fuel in diesel engine, the brake specific fuel consumption (BSFC) increased than diesel fuel for four hole nozzle. However, $\mathrm{CO}, \mathrm{SO}, \mathrm{HC}$ decreases and $\mathrm{NO}_{\mathrm{x}}$ emissions increases due to higher temperature generate in engine [16]. Standard 3 holes nozzle and 210 bar injection pressure yielded lowest brake specific fuel consumption. Also, it was observed that for the same number of holes, small size hole nozzle at any given injection pressure yielded better performance. This is indicating the fact that the smaller nozzle requires higher injection pressure to ensure complete combustion and to bring down fuel consumption [17].

\section{Fuel Properties}

The major properties of the fuels have shown in below Table 2.1.

\section{TABLE 2.1. PROPERTIES OF BIODIESEL BLENDS}

\begin{tabular}{|c|c|c|c|c|c|c|}
\hline Property & Diesel & TPO & $\begin{array}{c}\text { TPO } \\
\mathbf{2 0}\end{array}$ & $\begin{array}{c}\text { TPO } \\
\mathbf{4 0}\end{array}$ & $\begin{array}{c}\text { TPO } \\
\mathbf{6 0}\end{array}$ & $\begin{array}{c}\text { TPO } \\
\mathbf{8 0}\end{array}$ \\
\hline $\begin{array}{c}\text { Density at } \\
30^{\circ} \mathrm{C}\end{array}$ & 820 & 908 & 840 & 856 & 870 & 882 \\
\hline $\begin{array}{c}\text { Kinematic } \\
\text { viscosity } \\
\text { at } 40^{\circ} \mathrm{C} \\
\left(\mathrm{m}^{2} / \mathrm{sec}\right)\end{array}$ & 2.07 & 3.80 & - & - & - & - \\
\hline $\begin{array}{c}\text { Calorific } \\
\text { value } \\
(\mathrm{KJ} / \mathrm{Kg})\end{array}$ & 44800 & 43801 & 43580 & 43360 & 42940 & 42720 \\
\hline $\begin{array}{c}\text { Sulphur } \\
\text { content } \\
(\%)\end{array}$ & $<0.045$ & $<0.080$ & - & - & - & - \\
\hline $\begin{array}{c}\text { Flash } \\
\text { point }{ }^{\circ} \mathrm{C}\end{array}$ & 50 & 42 & - & - & - & - \\
\hline $\begin{array}{c}\text { Fire point } \\
{ }^{\circ} \mathrm{C}\end{array}$ & 56 & 45 & - & - & - & - \\
\hline
\end{tabular}

\section{Experimental Setup and Procedure}

\subsection{Engine test}

A single cylinder four stroke water cooled diesel engine developing a power output of $3.7 \mathrm{KW}$ i.e. $5 \mathrm{HP}$ at rated speed of $1500 \mathrm{rev} / \mathrm{min}$ is used for the work. The specifications of the engine are shown in Table 3.1. The Schematic of the experimental setup is shown in Fig. 3.1. A DC shunt dynamometer is used for loading the engine.
A DC shunt dynamometer is used for loading the engine. The fuel flow rate has measured by volume through a burette. The experiment has been conducted to run at constant compression ratio of $16.5: 1$, injection pressure of 200 bar and with a 3 hole injector nozzle.

\section{TABLE 3.1. ENGINE SPECIFICATIONS}

\begin{tabular}{|c|c|}
\hline Make & Kirloskar engines Ltd. \\
\hline Cooling system & Water cooled \\
\hline No. of cylinder & 1 \\
\hline Type & Direct injection, Four stroke \\
\hline Bore $\times$ stroke $(\mathrm{mm})$ & $80 \times 110$ \\
\hline Compression ratio & $16.5: 1$ \\
\hline Rated power $(\mathrm{kW}-\mathrm{HP})$ & $3.7 \mathrm{~kW}-5 \mathrm{HP}$ \\
\hline Rated speed & $1500 \mathrm{rpm}$ \\
\hline Swept volume & $553 \mathrm{cc}$ \\
\hline Fuel injection timing & $23^{\circ}$ before TDC \\
\hline Injection pressure & 200 bar \\
\hline Injector nozzle & 3 holes nozzle \\
\hline
\end{tabular}

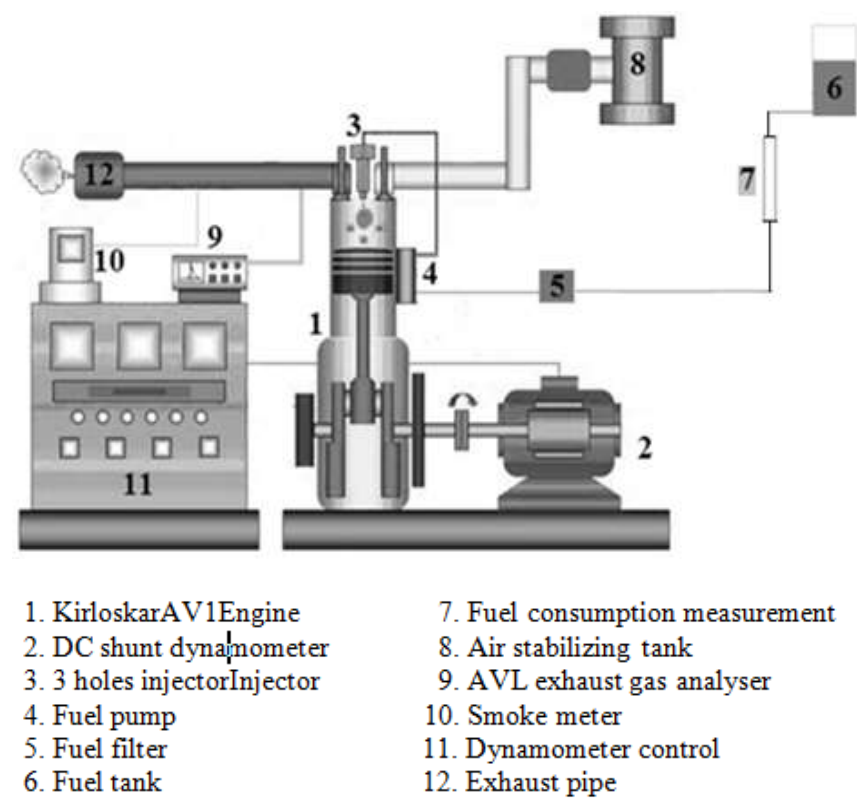

Fig. 3.1. Schematic of experimental setup

\subsection{Emission instrumentation \\ 3.2.1. Exhaust Gas Emission Analyzer}

Exhaust gas emission analysis requires measurement of concentrations of regulated exhaust gases such as carbon monoxide (CO), unburned hydrocarbons ( $\mathrm{HC}$ ), carbon dioxide $\left(\mathrm{CO}_{2}\right)$ in the engine exhaust. AVL digas 444 gas analyzer was used for exhaust gas measurement.

\subsubsection{Smoke Opacity Measurement}

The opacity of the exhaust gas is measured by 
Hartridge Smoke meter. The smoke opacity quantifies the amount of particulate matter present in the engine exhaust. The Bosch smoke meter usually consists of a piston type sampling pump and a smoke level measuring unit. Two separate sampling probes were used to receive sample exhaust gases from the engine, for measuring emission and smoke intensity separately. The filter paper of $4.5 \mathrm{~cm}$ diameter was used to collect smoke samples (from the engine) through the smoke sampling pump for measuring the Bosch Smoke opacity.

\subsection{Experimental procedure}

Necessary modifications and instrumentation of test engine was done and the experiments were performed as per to the objectives. Initially experiment has performed on the conventional $\mathrm{CI}$ engine at an engine speed of $1500 \mathrm{rpm}$ with five different engine loads, with constant $23^{\circ}$ BTDC injection timing, three holes nozzle injector, 200 bar injection pressure and 16.5:1 compression ratio with diesel as fuel to generate baseline data. Then experiments have conducted with TPO 20, TPO 40, TPO 60, TPO 80 and TPO as fuel with the same engine setup and above procedure. Obtained results of TPO blends compared for the performance and emission characteristics of diesel fuel.

\section{Results and Discussions}

\subsection{Brake specific fuel consumption}

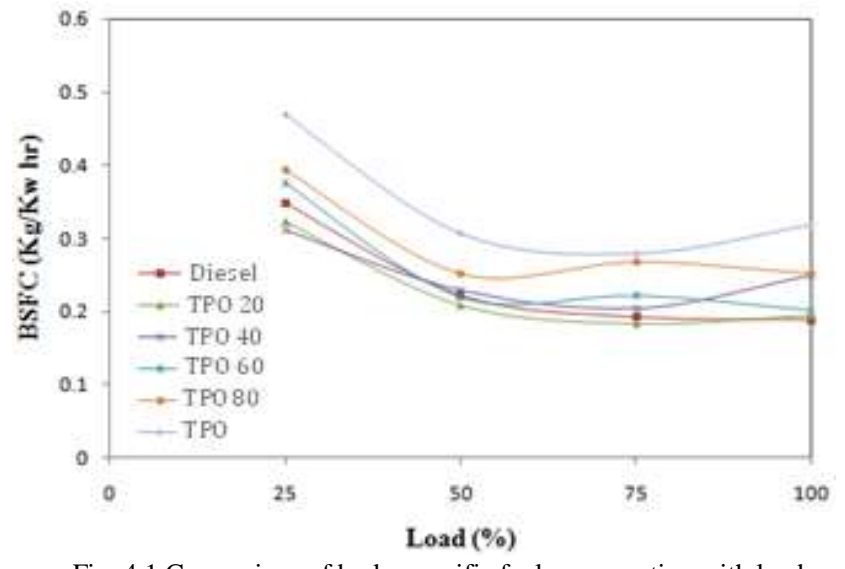

Fig. 4.1 Comparison of brake specific fuel consumption with load

The brake specific fuel consumption (BSFC) gives value that is more reliable when two different fuels of different heating values and densities blend each other. Figure 4.1 shows the comparison of the brake specific fuel consumption of TPO-diesel blend with diesel for 3 holes nozzle fuel injector. Among all TPO 20 has good BSFC. It can also see that BSFC is higher with increase in the concentration of TPO in TPO-Diesel blend. This behavior may be due to low calorific value of TPO-Diesel blends. Here the viscosity and density of fuel leads to decrease the BSFC.

\section{2. $\quad$ Brake thermal efficiency}

The below Fig. 4.2 shows the variation of brake thermal efficiency with load for TPO-diesel blends with 3 holes fuel injector nozzle. The brake thermal efficiency is $19.02 \%$ at full load for diesel. However, when the engine fueled with TPOdiesel blends such as TPO 20, TPO 40, TPO 60, TPO 80 and TPO it has given the lower thermal efficiencies of $18.45 \%$, $14.37 \%, 17.82 \%, 14.27 \%$ and $11.29 \%$ respectively at full load. Also observed from the Fig. 4.2 that waste tyre oil blends shows the lower brake thermal efficiency. This is due to lower calorific value of TPO-diesel blends than diesel. Further, among all the blends, TPO 20 has higher brake thermal efficiency may due to lower viscosity.

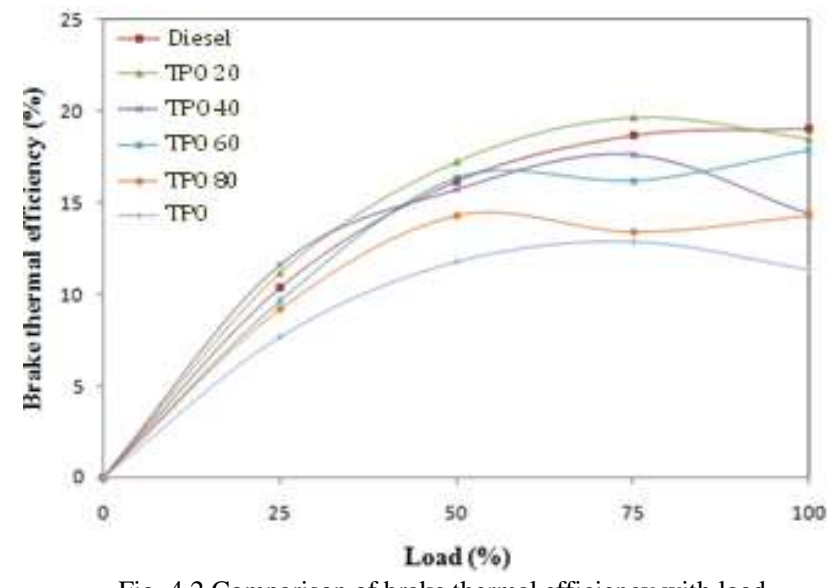

Fig. 4.2 Comparison of brake thermal efficiency with load

\subsection{HC emissions}

Unburned fuel is the main reason for hydrocarbon emission. Unburned hydrocarbon is a useful measure of combustion inefficiency. The variation of unburned hydrocarbon with load for 3 holes nozzle for tested fuels is shown in Figure 4.3. The hydrocarbon emission is decreasing with increase in the load. HC varies from 31 PPM at low load to 24 PPM at full load for diesel fuel, and it varies from 24 PPM at low load to 31 PPM at full load for TPO 60. Similarly, for TPO 80 it varies from 20 PPM at low load to 38 PPM at full load, for TPO it varies from 43 PPM to 50 PPM.

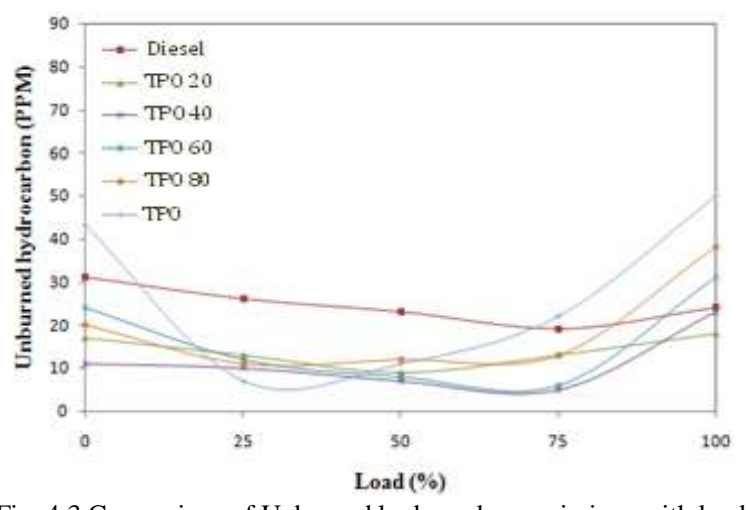

Fig. 4.3 Comparison of Unburned hydrocarbon emissions with load 
The higher HC emission in blend compared to diesel has attributed to the reason that the viscosity of TPO-DF blends decrease with increase in concentration of TPO. Hence, the fuel spray for TPO-Diesel blends in case of 3 holes might have impingement on the wall due to which hydrocarbon remain along the cylinder wall which results in higher level of unburned hydrocarbon. For TPO 20 the unburned hydrocarbons reduced remarkably due to the oxygen present in the biodiesel.

\subsection{Carbon monoxide emissions}

The variation of carbon monoxide with load for 3 holes fuel injector is shown in Figure 4.4. Carbon monoxide emission is mainly due to the lack of oxygen, poor air entrainment, mixture preparation and incomplete combustion during the combustion process.

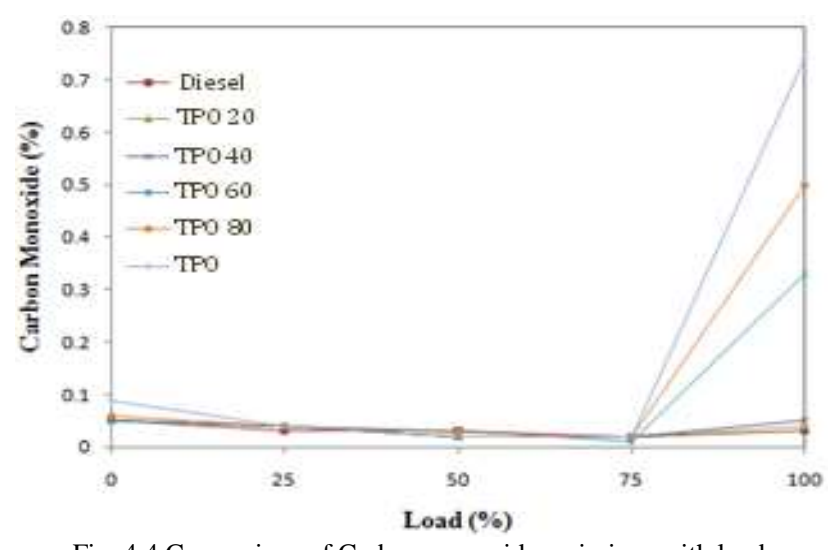

Fig. 4.4 Comparison of Carbon monoxide emissions with load

$\mathrm{CO}$ emission is toxic and must be controlled. It is an intermediate product in the combustion of a hydrocarbon fuel, so its emission results from incomplete combustion. The $\mathrm{CO}$ emission varies from $0.05 \%$ at low load to $0.03 \%$ at full load for diesel. For TPO 60, it varies from $0.05 \%$ at low load to $0.33 \%$ for full load, for TPO 80 it is 0.06 at low load to $0.5 \%$ at full load and from $0.09 \%$ at low load to $0.74 \%$ at full load for TPO. The results show that $\mathrm{CO}$ emission of waste tyre oil is higher than diesel especially at higher load and higher blend. The reason behind increased $\mathrm{CO}$ emission is incomplete combustion due to absence of oxygenated compounds in waste tyre oil. The drastic increase in CO emission at higher loads is due to higher fuel consumption.

The results show that $\mathrm{CO}$ emission of TPO-Diesel Fuel blends is higher than diesel that attributes to poor mixture preparation, local rich regions and absence of oxygenated compounds in waste tyre oil.

\subsection{Carbon dioxide emissions}

Fig. 4.5 illustrates the variation of carbon dioxide emission for various blends of waste tyre oil and diesel fuel at varying loads with 3 holes fuel injector nozzle.
Carbon dioxide occurs naturally in the atmosphere and is a normal product of combustion. Ideally, combustion of a $\mathrm{HC}$ fuel should produce only $\mathrm{CO}_{2}$ and water $\left(\mathrm{H}_{2} \mathrm{O}\right)$. The $\mathrm{CO}_{2}$ emission varies from $1.2 \%$ at low load to $2.7 \%$ at full load for diesel fuel. For TPO 60, it varies from $1.2 \%$ at low load to $2.5 \%$ at full load, from $1.2 \%$ at low load to $2.4 \%$ at full load for TPO 80. For TPO, it varies from $1.3 \%$ at low load to $2.2 \%$ at full load. The carbon dioxide emission for the blends is lower than diesel. This may be due to late burning of fuel leading to incomplete oxidation of $\mathrm{CO}$.

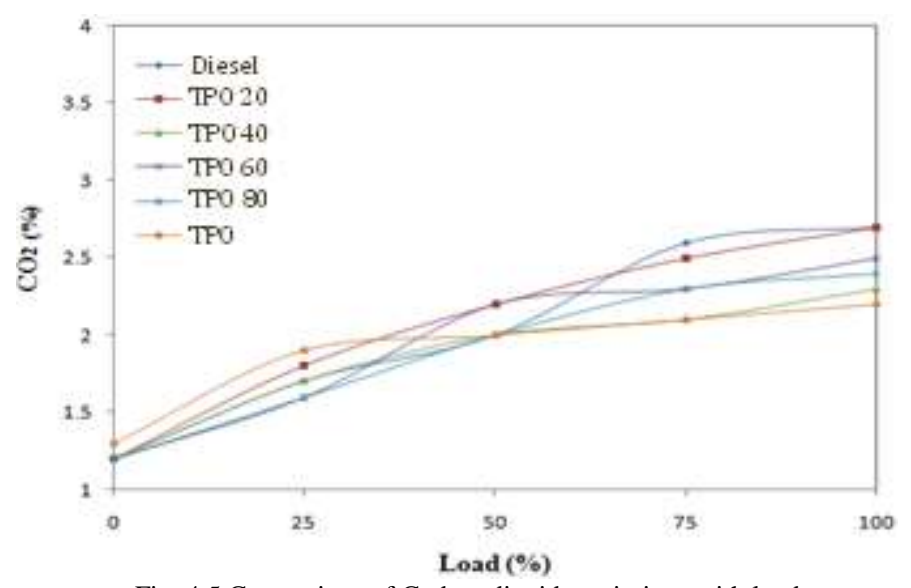

Fig. 4.5 Comparison of Carbon dioxide emissions with load

\subsection{Smoke emissions}

The variation of smoke emission with respect to load for different TPO-Diesel blend with 3 hole injector is shown in Fig. 4.6. The smoke value for Diesel at full load is $21 \%$, whereas for TPO 60, TPO 80, TPO it is $43 \%, 50 \%, 60 \%$ respectively. It is increasing with the increase in TPO concentration. It has known that soot precursors formed during premixed combustion phase and if, the premixed combustion phase is more pronounced there is more time available for carbon particles to combine with oxygen and combust properly. In the present case, the premixed combustion phase has less pronounced hence, more smoke at all the blends.

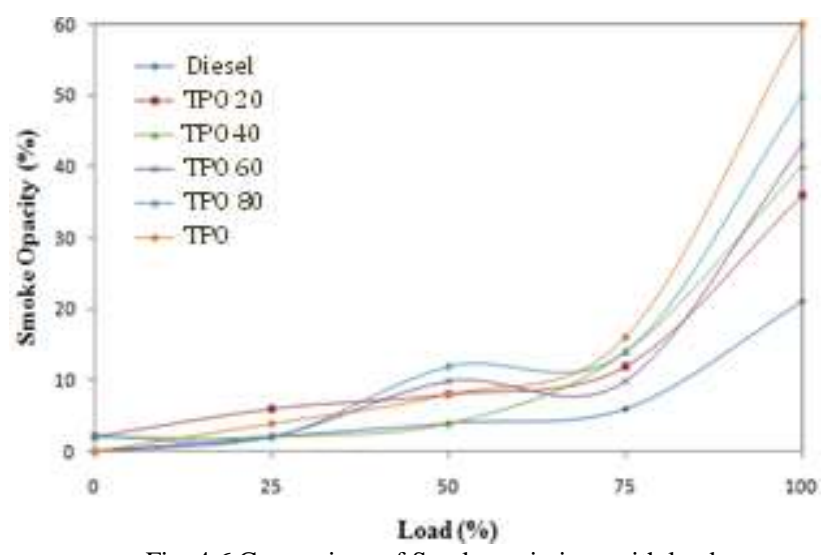

Fig. 4.6 Comparison of Smoke emissions with load 


\section{v. Conclusions}

TPO and its blends with diesel were used in DI diesel engine and its effect on performance parameters and exhaust gas emissions were studied for 3 holes fuel injector. The following conclusions drawn based on experimental results and associated data analysis:

- Brake thermal efficiency decreased with increase in concentration of TPO.

- $\quad$ BSFC have reduced by reducing the concentration of TPO.

- $\quad \mathrm{HC}$ emissions have reduced at all loads condition for TPO 20.

- $\mathrm{CO}, \mathrm{HC}$ and smoke emissions increased with increase in concentration of TPO due to poor mixture preparation, local rich regions and absence of inherent oxygen in TPO.

- Emissions from waste tyre oil may be high, but if we consider its overall impact on the environment than it might be helping in the reduction of pollution.

The main advantage of TPO is engine can run with $100 \%$ waste tyre oil.

\section{References}

[1] Adrian.M.Cunnliffe, Williams.P.T, 1998, Journal of Applied and Analytical Pyrolysis, 44, 131-152.

[2] Mani M, Nagarajan G. "Influence of injection timing on performance, emission and combustion characteristics of a DI diesel engine running on waste tyre oil". Energy 2009;34:1617-23.

[3] I de Marco Rotriguez, Laresgoiti.M.F, Carbero, M.A., Torres.A, Chomon. M.J., Caballero. B., 2001, Pyrolysis of Scrap Tyres, Fuel Processing Technology, 72, 9-22.

[4] Consea JA, Font R, Marcilla A, Garcia AN. "Pyrolysis of polyethylene in a fluidized bedreactor". Energy Fuel 1994;8:1238-46.

[5] S. Murugan, M.C. Ramaswamy, G. Nagarajan, "Production of tyre pyrolysis oil from waste automobile tyres", National Conference on Advances in Mechanical Engineering, 2006, pp. 899-906.

[6] Beltrame PL, Carniti P, Audisio G, Bertini F. "Catalytic degradation of polymers". Part II - Degradation of polyethylene. Polym Degrad Stabil 1989;26:209-20.

[7] Bagri R, Williams PT. "Catalytic pyrolysis of polyethylene". J Anal Appl Pyrol 2002;63:29-41.

[8] Venuto PB, Habib ET. "Fluid catalytic cracking with zeolite catalysts". New York: Marcel Dekker Inc.; 1979.

[9] Sharratt PN, Lin YH, Garforth AA, Dwyer J. "Investigation of the catalytic pyrolysis of high-density polyethylene over a HZSM-5 catalyst in a laboratory fluidized-bed reactor". Indus Eng Chem Res 1997;36(5):118-24.

[10] Miskolczi N, Bartha L. "Investigation of hydrocarbon fractions form waste tyre recycling by FTIR, GC, EDX RFS and SEC techniques". J Biochem Bioph Meth 2008;70:1247-53.

[11] Seo YH, Lee KH, Shin DH. "Investigation of catalytic degradation of high-density polyethylene by hydrocarbon group type analysis". J Anal Appl Pyrol 2003;70:383-98.

[12] Park JW, Kim JH, Seo G. "The effect of pore shape on the catalytic performance of zeolites in the liquid-phase degradation of HDPE". Polym Degrad Stabil 2002;76:495-501.

[13] Panda AK, Singh RK. "Catalytic performances of kaoline and silica alumina in the thermal degradation of polypropylene". I Fuel Chem Technol 2011; 39(3):198-202.

[14] Panda AK, Singh RK, Mishra DK. "Thermo-catalytic degradation of thermocol waste to value added liquid products". Asian J Chem 2012;24(12):5539-42.
[15] Mr. Lijo P Varghese et.al., "analysis of the effect of nozzle hole diameter on CI engine performance using karanja oil-diesel blends", International journal of mechanical engineering and technology, IF (2013):5.7731, volume 4,pp.79-88.

[16] Cenk Sayin et. al., "Influence of injector hole number on the performance and emissions of a DI diesel engine fueled with biodiesel diesel fuel blends", Applied Thermal Engineering 61 (2013), pp.121128.

[17] USV Prasad et al., "Influence of Fuel Injection Parameters of DI Diesel Engine Fuelled With Biodiesel and Diesel Blends", International Conference on Mechanical, Automobile and Robotics Engineering, Penang. Malaysia (2012), pp.261-264.

About Author (s):

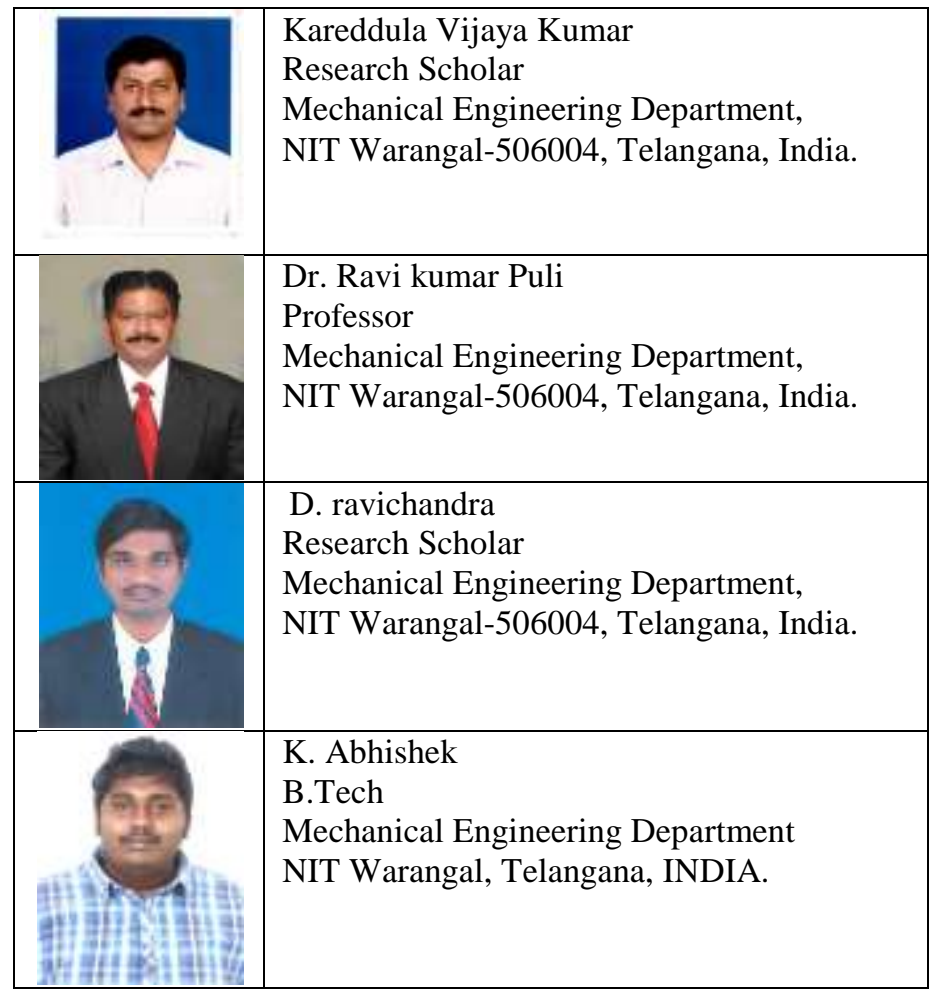

